\title{
Brown and Beige Fat: Therapeutic Potential in Obesity
}

\author{
Anna Meiliana ${ }^{1,2, *}$, Andi Wijaya ${ }^{2,3}$ \\ ${ }^{1}$ Postgraduate Program in Clinical Pharmacy, Padjadjaran University, Jl. Eijkman No.38, Bandung, Indonesia \\ ${ }^{2}$ Prodia Clinical Laboratory, Jl. Cisangkuy No.2, Bandung, Indonesia \\ ${ }^{3}$ Postgraduate Program in Clinical Biochemistry, Hasanuddin University, Jl. Perintis Kemerdekaan Km.10, Makassar, Indonesia \\ ${ }^{*}$ Corresponding author. E-mail: anna.meiliana@prodia.co.id
}

\section{Abstract}

$\mathrm{B}$ ACKGROUND: The epidemic of obesity and type 2 diabetes presents a serious challenge to scientific and biomedical communities worldwide. There has been an upsurge of interest in the adipocyte coincident with the onset of the obesity epidemic and the realization that adipose tissue plays a major role in the regulation of metabolic function.

CONTENT: Adipose tissue, best known for its role in fat storage, can also suppress weight gain and metabolic disease through the action of specialized, heat-producing adipocytes. Brown adipocytes are located in dedicated depots and express constitutively high levels of thermogenic genes, whereas inducible 'brown-like' adipocytes, also known as beige cells, develop in white fat in response to various activators. The activities of brown and beige fat cells reduce metabolic disease, including obesity, in mice and correlate with leanness in humans. Many genes and pathways that regulate brown and beige adipocyte biology have now been identified, providing a variety of promising therapeutic targets for metabolic disease.

SUMMARY: The complexity of adipose tissue presents numerous challenges but also several opportunities for therapeutic intervention. There is persuasive evidence from animal models that enhancement of the function of brown adipocytes, beige adipocytes or both in humans could be very effective for treating type 2 diabetes and obesity. Moreover, there are now an extensive variety of factors and pathways that could potentially be targeted for therapeutic effects. In particular, the discoveries of circulating factors, such as irisin, fibroblast growth factor (FGF) 21 and natriuretic peptides, that enhance brown and beige fat function in mice have garnered tremendous interest. Certainly, the next

Abstrak

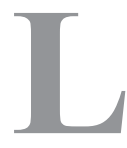

ATAR BELAKANG: Epidemi obesitas dan diabetes tipe 2 menghadirkan tantangan yang serius bagi komunitas ilmiah dan biomedik di seluruh dunia. Terjadi peningkatan minat terhadap adiposit, bersamaan dengan onset epidemi obesitas dan kesadaran bahwa jaringan adiposa memainkan peran utama pada pengaturan fungsi metabolisme.

ISI: Jaringan adiposa, terkenal karena fungsinya sebagai penyimpanan adiposa, juga dapat menekan kenaikan berat badan dan penyakit metabolisme melalui adiposit khusus yang menghasilkan panas. Adiposit coklat terletak pada cadangan tertentu dan secara terus menerus mengekspresikan gen termogenik dalam kadar tinggi, sementara itu adiposit "brown-like", yang dikenal sebagai sel beige, berkembang di dalam jaringan adiposa putih sebagai respon dari berbagai aktivator. Aktivitas sel adiposa coklat dan beige mengurangi penyakit metabolisme, termasuk obesitas, pada tikus dan berhubungan dengan kerampingan pada manusia. Beberapa gen dan jalur yang mengatur adiposit coklat dan beige telah teridentifikasi, dan menjadi target terapi yang menjanjikan bagi penyakit metabolisme.

RINGKASAN: Kompleksitas jaringan adiposa menghadirkan berbagai tantangan dan juga kesempatan bagi terapi intervensi. Beberapa bukti persuasif pada hewan coba menunjukkan bahwa peningkatan fungsi adiposit coklat, beige, atau keduanya pada manusia sangat efektif untuk mengobati diabetes tipe 2 dan obesitas. Lebih lagi, ada berbagai faktor dan jalur ekstensif yang berpotensi sebagai target terapi. Secara khusus, penemuan faktor sirkulasi seperti irisin, fibroblast growth factor (FGF)21, dan natriuretic peptide, yang mampu meningkatkan fungsi adiposa coklat dan beige, telah menarik banyak perhatian. 
decade will see massive efforts to use beige and brown fat to ameliorate human metabolic disease.

KEYWORDS: obesity, white adipose tissue, brown adipose tissue, beige adipose tissue, adipose organ, thermogenesis, energy expenditure

Indones Biomed J. 2014; 6(2): 65-78
Tentu saja, dekade berikut akan menunjukkan usaha besar-besaran penggunaan adiposa coklat dan beige untuk mengatasi penyakit metabolisme.

KATA KUNCI: obesitas, jaringan adiposa coklat, jaringan adiposa beige, organ adiposa, thermogenesis, pengeluaran energi

that activate brown fat or induce the conversion of white fat to brown-like fat could help treat metabolic diseases such as obesity and diabetes.

\section{Adaptive Thermogenesis (AT) and} Weight Loss

Cellular bioenergetics are considered as a suitable target for antiobesity therapy. The capacity of energy production, heat release, and metabolic adaptations to either starvation, diet, cold, stress, and inflammation differ between subjects. Although the metabolic basis of these adaptations as well as the intraindividual and interindividual variances between them still remain to be characterized, modulation of AT to affect energy balance is challenging; its main regulators, that is, either sympathetic nervous system (SNS) activity, 3,5,3'-tri-iodothyronine (T3), and/or leptin may provide a suitable basis for pharmacotherapies.(19)

AT has been defined as the change in energy expenditure following acute and/or long-term overfeeding and underfeeding. In some studies, it has also been investigated by using catecholamines, caffeine, ephedrine and adrenergic blockers to induce changes in thermogenesis. As previously described (20), these stimuli were found to induce statistically significant changes in thermogenesis. (21) AT may represent a defense mechanism that is set to protect energy stores from accelerated growth or depletion. The first explanation that has been proposed to explain thermogenic variations in animals is related to the activity of BAT. As described by Rothwell and Stock (22), BAT activity has sufficient impact on energy metabolism to explain individual variations in the proneness to obesity. Beyond the demonstration of validity of the greater-thanpredicted change in energy expenditure as a measure of adaptive thermogenesis (23), Rosenbaum et al. (24) have also contributed to identify some metabolic correlates of this variable. Indeed, a decrease in thermogenesis in weighreduced obese individuals was found to be associated with a decrease in plasma T3 and leptin, as well as sympathetic nervous system activity.(24) 
Although weight reduction is a difficult task, the maintenance of lost weight seems to require the deployment of even more efforts.(25) Indeed, the relapse of more than $80 \%$ of individuals to pre-weight-loss levels of body fatness after otherwise successful weight loss is likely due to the coordinated actions of metabolic, neuroendocrine, autonomic and behavioral changes that oppose the maintenance of a reduced body weight.(26) The occurrence of an apparent resistance to lose fat (plateau) is often interpreted as being the result of a lack of dietary and/or physical activity guidelines compliance. However, the adaptive reduction in thermogenesis can be sufficiently pronounced in some cases to counteract further weight loss, even in the compliant patients. $(20,27,28)$

As these thermogenic changes would seem to persist over time, they likely contribute to body weight regain following body weight loss. It thus seems important to further investigate adaptive thermogenesis in humans, be it for the development of relevant biomarkers or to improve diagnosis about individual determinants of the predisposition to obesity.(21) The existence of beige fat cells may represent an evolutionarily conserved cellular mechanism to provide flexibility in adaptive thermogenesis. It is likely that these beige adipocytes, rather than the classical brown fat cells, remain present in the adult state of larger mammals in which hypothermia is a less frequent threat than in rodents.(1) The therapeutic potential of activating brown-fat-mediated thermogenesis in human has yet to be fulfilled. Trials of drugs that increase the b-adrenergic activation of BAT have not been successful in humans due to either lack of efficacy or to intolerable side effects resulting from activation of $\beta$-adrenergic receptors in other tissues. Clearly, there is a need to develop more specific means to activate brown fat in humans in more specific ways. $(29,30)$

\section{BAT}

The most important single idea in the field of metabolic disease is the concept of energy balance. This means that, with the rare exception of mal-absorption of nutrients, an animal cannot gain or lose weight unless there is an imbalance between food intake and energy expenditure. When energy intake chronically exceeds energy expenditure, weight gain and obesity result. This excess weight is stored in adipose tissue, which consists of fat cells, or adipocytes, which have an incredible capacity for storing surplus energy in the form of lipid. This tissue is not just a passive storage depot, but also an endocrine organ, secreting molecules like leptin that can regulate appetite and whole-body metabolism. In addition to these well-described energy-storing fat cells, adipocytes also exist that are highly effective at transforming chemical energy into heat. Brown adipocytes, which get their name from their high number of iron-containing mitochondria, are specialized to dissipate energy in the form of heat, a process called non-shivering thermogenesis. Classical BAT is typically located in the interscapular region and is most easily detected in infants and small mammals. It is referred to as "classical" in distinction from the inducible or beige adipocyte, which has unique molecular and developmental characteristics.(31) BAT specializes in burning fat and is responsible for adaptive, nonshivering thermogenesis in mammals.(32)

$\mathrm{UCP} 1$ is responsible for non-shivering thermogenesis in BAT. Upon activation by long-chain fatty acids (LCFAs), UCP1 increases the conductance of the inner mitochondrial membrane (IMM) to make BAT mitochondria generate heat rather than adenine triphosphate (ATP).(33) BAT burns fatty acids for heat production to defend the body against cold $(32,34)$ and has recently been shown to be present in humans. $(3,4,35)$ Triglyceride-rich lipoproteins (TRLs) transport lipids in the bloodstream, where the fatty acid moieties are liberated by the action of lipoprotein lipase (LPL).(36) Increased BAT activity induced by short-term cold exposure controls TRL metabolism in mice. Cold exposure drastically accelerated plasma clearance of triglycerides as a result of increased uptake into BAT, a process crucially dependent on local LPL activity and trans-membrane receptor CD36. In pathophysiological settings, cold exposure corrected hyperlipidemia and improved deleterious effects of insulin resistance.(37)

BAT is a highly energetic organ that not only utilizes its unique expression of UCP1 for uncoupling of respiration (i.e., cold or diet-induced thermogenesis), but is also a mitochondrially rich tissue that uses glucose and fatty acids as a fuel.(3,37-39) Adult humans have substantial depots of metabolically active BAT $(3-5,7)$, suggesting that BAT may play a fundamental role in the maintenance of a leaner and more metabolically healthy phenotype.

Cold exposure is the most powerful and physiological stimulus for BAT activation, both in small rodents and in humans.(7,40-44) It is known that the stimulatory effects of cold on BAT are mediated through the activation of the sympathetic nervous system, initiated by peripheral stimulation of transient receptor potential (TRP) channels in sensory neurons. $(41,45)$ This pathway is also activated by some food ingredients, such as capsaicin and capsinoids, nonpungent capsaicin analogs.(46,47) Stimulation of TRP channels by capsinoids is effective for enhancement of BAT thermogenesis and upregulation of UCP1, a key molecule 
of BAT thermogenesis, in mice.(47) It is therefore expected that the reactivation and/or recruitment of BAT may protect against the onset of obesity and related metabolic disorders in humans.(48)

\section{Beige Adipose Tissue}

The last few years have seen a paradigm shift with regard to the understanding of the origin of and relationship between adipose tissues. A series of investigations have demonstrated cell lineage. $(10,52)$ This is exemplified by the interscapular BAT depots and the perirenal BAT depot, a depot that contains a mixture of classical brown and white adipocytes. $(10,53)$ In addition, UCP1-positive, brown fat-like cells can emerge in most WAT depots upon prolonged cold exposure or $\beta$-adrenergic receptor activation.(54-56) These brown fat cells, which are not derived from a myf5-positive lineage, are designated beige or brown-in-white (beige) cells. $(9,57)$

Compared with WAT, BAT is more extensively vascularized, and VEGF- $\alpha-$ dependent angiogenesis has been shown to be important for the thermogenic response to

\section{SHADES OF A CELL}

Three distinct types of fat cell have been identified to date, are there more to follow?

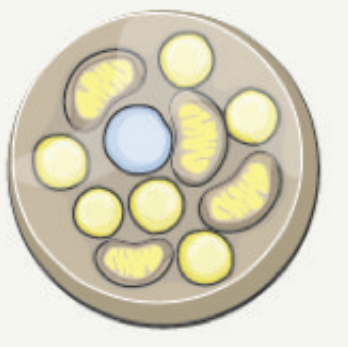

Brown fat cell

Converts chemical energy to heat to protect against cold weather.

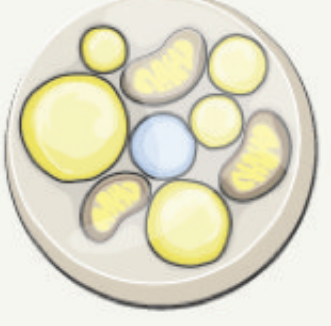

Beige fat cell Immature cell in white fat tissue matures to burn fat.

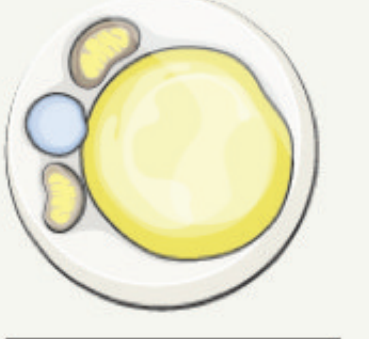

White fat cell

Most common fat cell, used to store fat and found beneath the skin and abdomen.

Figure 1. Shades of a cell.(58) (Adapted with permission from Nature Publishing Group).

that brown and white adipocytes are not sister cells, but rather, brown adipocytes are closely related to myocytes, and both originate from a common "adipomyocyte" precursor.(10,49,50) Furthermore, even among classical white adipocytes, it would seem that two types exist: the "genuine" white adipocytes and also "beige" adipocytes, a type of adipocyte that possesses the ability to express the UCP1, which until recently was believed to be a unique marker for brown adipocytes, but does not otherwise possess the full molecular characteristics of brown adipocytes. $(9,10,12)$

Recent studies found that each adipose depot examined was characterized by a unique marker gene expression pattern. However, despite this, we conclude that it is possible to divide the depots into three main types, the classical BAT depots, the beige adipose tissue depots, and the ("genuine") white adipose tissue (WAT) depots, and to associate particular gene expressions patterns with these depots.(51) It is now clear that there are two distinct types of brown adipose cells. One is the classical brown fat that arises from a myogenic factor 5 (myf5), muscle-like prolonged cold adaptation. (59) However, the role of BAT vascularity in maintaining systemic metabolic homeostasis under conditions of metabolic stress is unknown. Here, we show that obesity causes capillary rarefaction and hypoxia in BAT that is much more robust than in WAT. This condition leads to BAT "whitening" that is associated with diminished $\beta$-adrenergic signaling, the accumulation of large lipid droplets, and mitochondrial dysfunction and loss. These changes in the BAT microenvironment impair thermogenic responses and contribute to dysfunctional glucose metabolism.(60) Browning of rodent WAT can be brought about by hormones and cytokines, such as Irisin (61) and fibroblast growth factor (FGF) 21 (62), as well as by transcriptional modulation through PR domain containing (Prdm)16 (57), Forkhead box protein C2 (FoxC2) (63), receptor-interacting protein 140 (RIP140) (64), eukaryotic translation initiation factor 4E-binding protein 1 (4E-BP1) (65), transcriptional mediators/intermediary factor 2 (TIF2) (66), retinoblastoma protein (pRb) and p107 (67). However, there is an unmet need for strategies that would translate these mechanisms into the clinic. (68) 


\section{Adipose Organ Plasticity}

White adipose cells in mammals have the ability to store and release energy in the form of lipids. This function is essential as it allows intervals of fasting between meals and prolonged, week-long, fasting intervals. $(69,70)$ The large spherical shape of white adipocytes fits perfectly with their storage function because this geometric shape allows for maximum storage in minimal space. More than $90 \%$ of the volume of white adipocytes is occupied by a cytoplasmic unilocular lipid droplet consisting of triglycerides. White adipocytes are also able to secrete hormones (71) and several cytokines that influence instinctual behaviour and metabolic pathways (70).

Brown adipocytes are thermogenic cells that are highly regulated by the sympathetic nervous system to maintain body temperature when mammals are exposed to temperatures below thermoneutrality (approximately 28$\left.30^{\circ} \mathrm{C}\right)$. (72) To produce heat, brown adipocytes are activated by sympathetic nerves acting on beta3-adrenoceptors (beta3AR) to burn fatty acids in their unique spherical mitochondria, where the UCP1 protein in the inner membrane uncouples oxidative phosphorylation, resulting in energy dissipation in the form of heat.(32,73) Brown adipocytes store triglycerides in multiple small cytoplasmic lipid droplets so that they can rapidly burn large amounts of fatty acids.(74)

Brown and white adipocytes appear to have different morphology and opposing functions, but detailed anatomic studies have shown that both types are contained together in several locations, forming a multi-depot adipose organ $(75,76)$. Discrete depots are located in the subcutaneous space (subcutaneous depots) or in close vicinity to organs located in the trunk (visceral depots).(77) This finding has opened new perspectives in the physiological relationship between BAT and WAT, including the possibility of their reciprocal transformation (transdifferentiation) $(56,66,78)$. Harnessing the mechanism of WAT to BAT transdifferentiation could be useful to develop treatments for obesity and type 2 diabetes, because the absence of BAT or its adrenergic receptors results in obesity $(79,80)$ and transgenic mice overexpressing UCP1 in WAT are obesity resistant. $(81,82)$

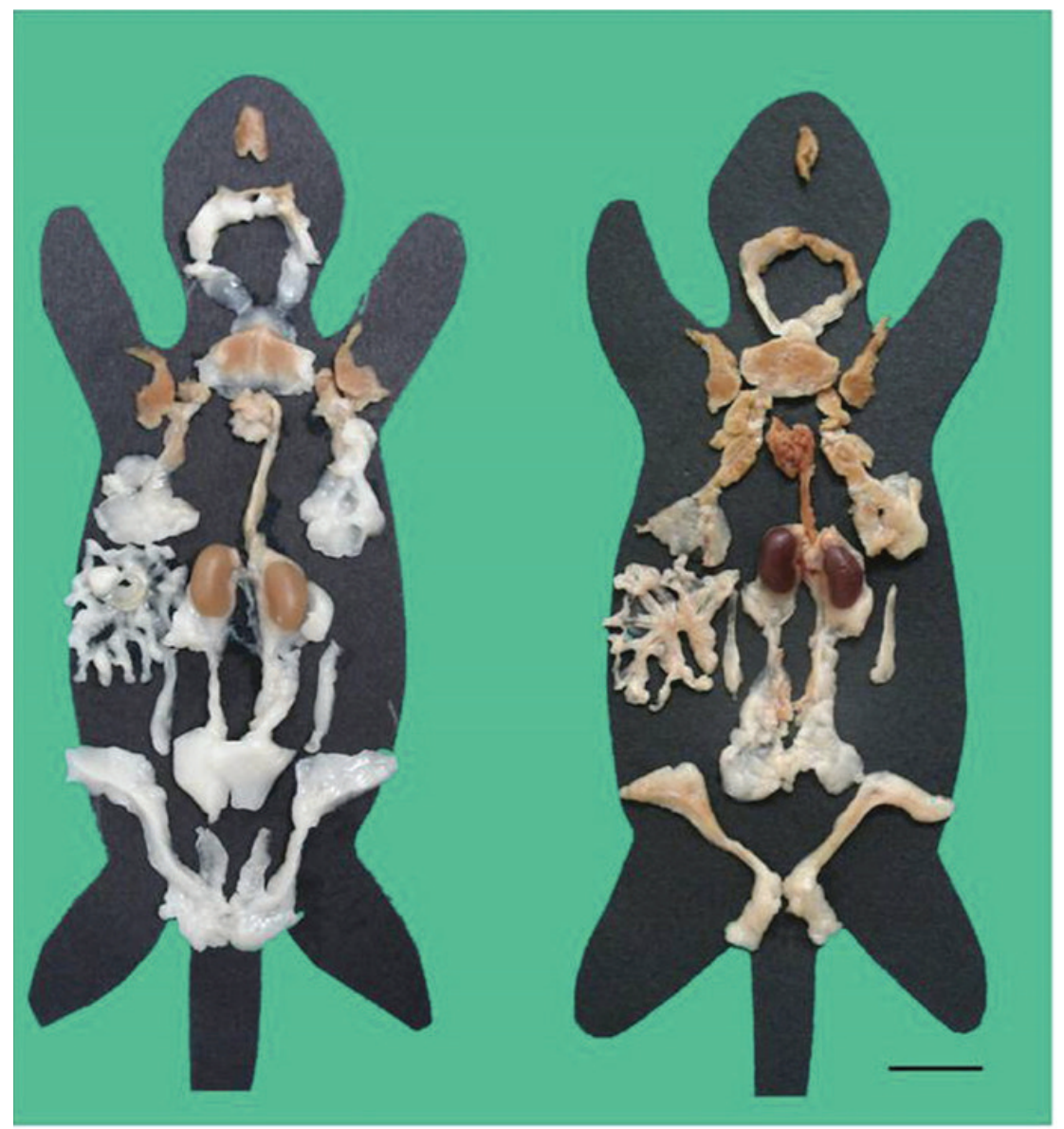

Figure 2. Multidepot adipose organ of adult C5 \& BL/6J female mice kept at $28^{\circ} \mathrm{C}$ (left) or $6^{\circ} \mathrm{C}$ (right) for 10 days.(82) (Adapted with permission from American Society for Biochemistry and Molecular Biology). 
Humans and mice harbour brown-like adipocytes in their predominantly white fat depots. $(54,83)$ These beige (brown-in-white) adipocytes are also known as beige, inducible brown or brown-like adipocytes. $(1,84,85)$ The abundance of this highly dynamic cell population is strainand location-dependent $(12,86)$ and it increases (beigening) in the cold whereas it decreases (whitening) in a warm environment $(83,87)$. The inguinal (posterior subcutaneous) depot constitutes the best studied and, owing to its size, the most important fat tissue capable of recruiting beige adipocytes.(51) Each depot is associated with specific nerve-vascular peduncles as are other organs in the body. Some researchers prefer to call these depots 'mini-organs' because of their autonomous anatomy and characteristics (88). Cinti et al. prefer the term 'adipose organ' to describe the general functional and plastic properties that are shared by most of its depots.(74)

Intermediate forms of adipocytes between white and brown adipocytes are present in all depots of the adipose organ. $(82,89)$ These intermediate adipocytes are multilocular but do not express the UCP1 protein, as indicated by immunohistochemistry. They also have mitochondria with intermediate features between those found in white and brown adipocytes. These cells could have a predominant lipid droplet and have been called paucilocular adipocytes.(56) Paucilocular adipocytes have a weak thermogenic capacity, in line with the idea that they are intermediate forms between white and brown adipocytes. These intermediate adipocytes are usually located in areas between WAT and BAT.(82)

The reason why white and brown adipocytes, with different morphology and physiology, are contained together in the same organ is unclear, but it should be noted that they both share important features, such as the ability to store and release lipids and the expression of beta3AR. $(90,91)$ Cinti et al. proposed a trans-differentiation theory: in specific physiologic conditions (chronic cold exposure), white adipocytes transform into brown adipocytes to supply the thermogenic needs, and conversely, brown adipocytes transform into white adipocytes when the energy balance is positive and the adipose organ requires increased storage capacity.(92) This plasticity is not limited to these conditions because during pregnancy, lactation or post-lactation states in females, white adipocytes seem to have the ability to convert into milk-secreting epithelial cells

Thus, adult humans seem to have expandable metabolically active brown adipocytes. In addition, it has been proven that animals with abundant natural (82) or induced $(81,93)$ BAT are resistant to obesity and that the administration of drugs that expand BAT is sufficient to curb obesity and related disorders in rats. $(55,94)$ Conversely, mice without functional brown adipocytes are prone to obesity and type 2 diabetes. $(79,80)$ The white / brown plasticity of adipose tissue might have considerable medical implications, since the brown-like phenotype seems to correlate with a reduced propensity for developing obesity and diabetes in mice. $(79-81,95,96)$

\section{Therapeutical Potential of Brown and Beige Fat}

The biomedical interest in brown and beige adipocytes has centered on the capacity of these cell types to counteract metabolic disease, including obesity and type 2 diabetes. Indeed, increased activities of brown and beige adipocytes have been linked to obesity resistance in many mouse models. $(57,63,81)$ The key question now is whether reduced thermogenic activity in fat cells is a cause or a consequence of weight gain in humans. Regardless of its natural role, increasing the activity of brown fat, beige fat or both through drugs or other methods holds tremendous promise for the treatment of metabolic disease.(97)

Most brown fat cells originate from precursor cells in the embryonic mesoderm that also give rise to skeletal muscle cells and a subpopulation of white adipocytes. $(10,52,98)$ These precursors transiently express Myf5 and paired box (Pax),(82) two genes that were previously thought to selectively mark skeletal myogenic cells in the mesoderm. $(10,52)$ Consistent with a developmental relationship between brown fat and muscle, brown fat precursor cells express a muscle-like gene signature, (50) and brown fat and muscle have related mitochondrial proteomes. (99) The embryonic origin and cell hierarchy of beige adipocytes is less clear. Beige and brown adipocytes probably come from distinct cell lineages, given that beige cells, at least in the subcutaneous depot, do not have a history of Myf5 expression. $(10,98)$

Over a decade ago, Himms-Hagen et al. (77) found that most beige adipocytes arise from pre-existing (nondividing) cells that they presumed were mature adipocytes. Since then, Cinti and others have provided substantial evidence in support of the idea that large unilocular white adipocytes transform into beige adipocytes in response to cold or $\beta 3$-adrenergic agonists. (82) Wang et al. indicates that most, if not all, beige adipocytes (at least in this subcutaneous depot) arise from a precursor population rather than from pre-existing adipocytes. 
a

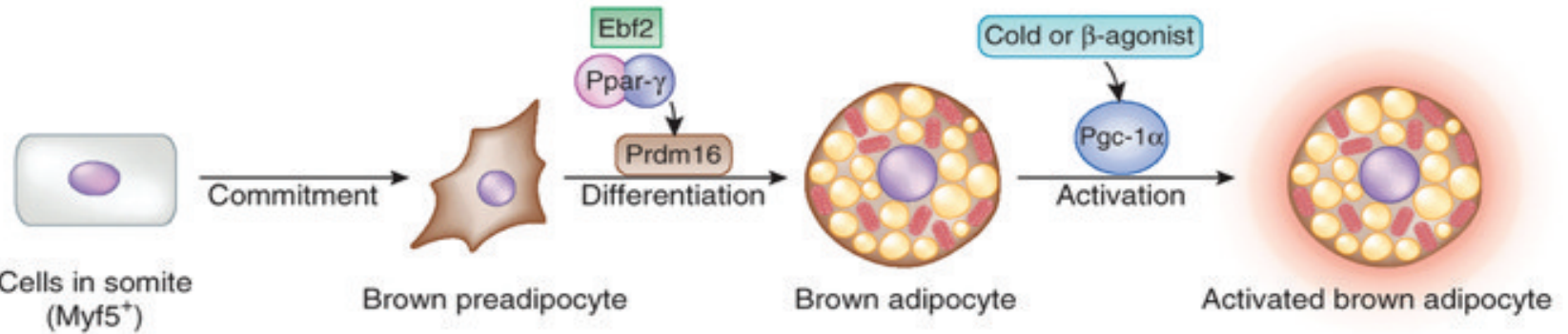

\section{b}

(Myt5 ${ }^{+}$)

Brown preadipocyte

Brown adipocyte

Activated brown adipocyte
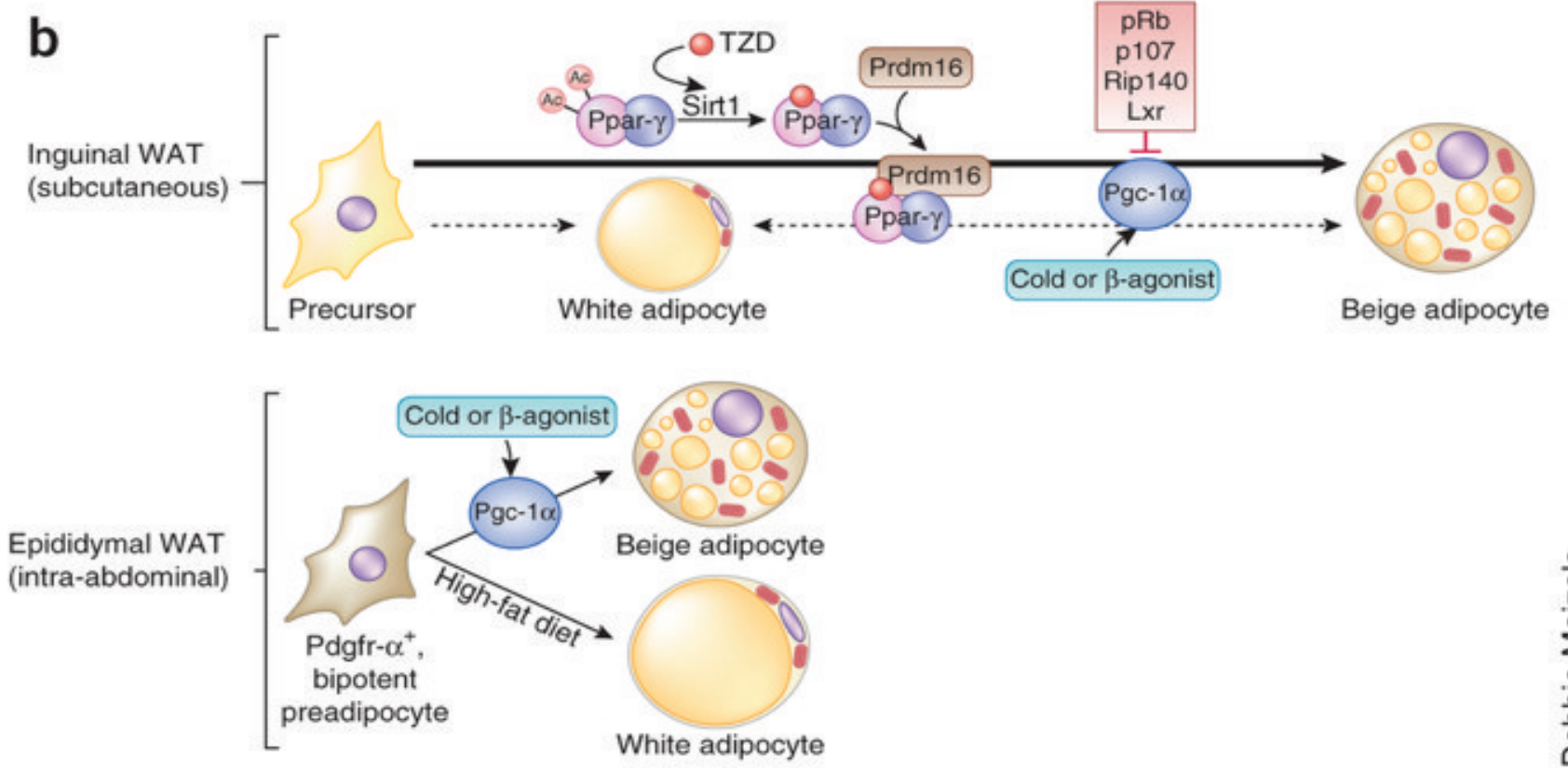

Figure 3. Transcriptional regulation of brown and beige adipocyte development.(97) (Adapted with permission from Nature Publishing Group).

The thermogenic profile of beige adipocytes is reversible. Beige adipocytes acquired in WAT during cold exposure lose UCP1 expression and are retained after mice are moved back to warmer conditions. When these mice are re-exposed to cold, the same cells again induce UCP1 expression.(101) Interestingly, the cells marked by previous UCP1 expression were not the only source of beige adipocytes during the second round of cold exposure. This suggests that beige adipocytes are retained and may function similarly to white fat cells for a certain period of time in animals that were previously cold. These beige adipocytes are presumably depleted through the normal mechanisms that control tissue turnover.(97)

Prdm 16 is a large zinc finger-containing transcriptional factor that is highly expressed in mouse BAT relative to visceral WAT.(102) Prdm16 expression is also substantially enriched in human BAT relative to adjacent subcutaneous WAT. $(5,103)$ Several factors have been shown to regulate brown and beige adipocyte differentiation by modulating Prdm16 expression or activity. Notable among these factors is bone morphogenetic protein 7 (BMP7), a signal that is essential for brown fat development, which increases the amounts of Prdm16 mRNA in brown and white fat precursor cells. $(84,104,105)$ Additionally, thiazolidinediones (TZDs), which agonize peroxisome proliferator-activated receptors (PPAR)- $\gamma$, induce thermogenic gene expression in fat cells through effects on Prdm16.(48,106)

Mice with increased activity of brown fat, beige fat or both resist weight gain but also display improvements in systemic metabolism, including improved glucose tolerance and increased insulin sensitivity.(61,63,107,108) Along these lines, activated brown fat takes up and metabolizes large quantities of lipid from the bloodstream, (37) which has beneficial effects on metabolism. The increased proportion of beige to white adipocytes in WAT modulates systemic insulin action through nonthermogenic mechanisms, perhaps by altering the secretome of adipose tissue. Additionally, thermogenic fat cells, not yet classified as brown or beige, that surround blood vessels (perivascular adipose) have been suggested to protect against the development of atherosclerosis.(109) Thus, the potential therapeutic uses of brown and beige fat go beyond obesity and should be 
considered for various metabolic disturbances, including type 2 diabetes, insulin resistance, atherosclerosis and lipid disorders.(97)

\section{Pharmacological and Nutritional Agents Promoting Browning of WAT}

Increasing energy expenditure is an attractive approach to fighting the worldwide epidemic in obesity and type 2 diabetes. Exercise is an important component of good health and represents the first line of therapy for humans with a variety of metabolic disorders: obesity, diabetes, and nonalcoholic hepatic steatosis. Recent data has shown that exercise, besides using calories to do physical work, also causes an increase in energy expenditure through augmentation in brown fat and the browning of white fat. $(61,110)$ Indeed, these effects on brown fat could represent part of the longer-lasting benefits of exercise.

That brown fat, in all of its dimensions, can improve type 2 diabetes and metabolic health seems to be settled science, at least in experimental animals. These cells express UCP1 and have a high mitochondrial content, thereby dissipating chemical energy in the form of heat. In fact, the improvements seen in glucose tolerance observed with "browning" of white fat and the formation of "beige" or "brite" cells might be greater than expected solely from their effects on body weight and adiposity.(111) Several polypeptides, including FGF21, BMP7/8b, brain natriuretic peptide (BNP)/atrial natriuretic peptide (ANP), and orexin, all have interesting browning effects. $(62,104,108,112,113)$

Irisin was of interest because it is induced during exercise in rodents and is at least partially responsible for the browning response observed in white fat during chronic exercise.(61) The parent polypeptide, fibronectin type III domain containing 5 (FNDC5), is synthesized as a type 1 membrane protein and is then cleaved and shed into the circulation as a highly glycosylated polypeptide of roughly $12 \mathrm{kDa}$. Irisin appears to act preferentially on the browning of white fat deposits when elevated in the blood of obese mice via viral vectors. This correlates with improvements in glucose tolerance in obese mice. Regarding human irisin, it is clear that FNDC5 mRNA is increased in skeletal muscle in some exercise paradigms but not others. $(61,114,115)$ Interestingly, two articles report that human patients with diabetes are deficient in irisin compared with normal counterparts.(116,117)

FGF21 is a recently discovered metabolic regulator. Exogenous FGF21 produces beneficial metabolic effects in animal models; however, the translation of these observations to humans has not been tested. Gaich et al. studied the effects of LY2405319, a variant of FGF21, in a randomized, placebo-controlled, double-blind proof-ofconcept trial in patients with obesity and type 2 diabetes. The results indicate that FGF21 is bioactive in humans and suggest that FGF21-based therapies may be effective for the treatment of selected metabolic disorders.(118)

Atrial natriuretic peptide and brain-type natriuretic peptide are released by the heart in response to heart failure or pressure overload. These factors reduce blood volume, blood pressure and cardiac output by dilating blood vessels and promoting salt and fluid excretion from the kidneys. Atrial natriuretic peptide is also known to promote lipolysis in adipocytes. Notably, high circulating concentrations of natriuretic peptides have also been associated with weight loss in humans. $(119,120)$ The effects of natriuretic peptides on brown and beige adipogenesis suggest that the control of adaptive thermogenesis is more complex than is currently appreciated. Cardiomyocytes, a cell type that is thought to have little crosstalk with adipocytes, can markedly alter the gene expression and function of adipose through the secretion of potent cardiometabolic hormones. Importantly, cold increases the concentrations of natriuretic peptides, suggesting that this browning system may have evolved, perhaps in epicardial fat, to safeguard cardiac function in animals during cold exposure.(97)

Cyclooxygenase-2 (COX2, the rate-limiting enzyme in prostaglandin synthesis) and WAT-derived prostaglandins (PGE2 and PGI2) appear to be crucially involved downstream of $\beta$-adrenergic stimulation in the induction of UCP1 expression in adipocytes in inguinal WAT, but not in classic interscapular brown adipocytes.(122,123) Overexpression of COX2 in WAT results in WAT browning, increased systemic energy expenditure, and protection against dietary obesity.(122) Importantly, evidence has been obtained that COX-dependent induction of UCP1 in WAT is important for diet-induced thermogenesis and energy balance in obesity-resistant mice.(123)

Capsaicin (8-methyl-N-vanillyl-6-nonenamide, a major ingredient in hot pepper widely used as a spice in food) and nonpungent capsaicin analogs (capsinoids) have an anti-obesity action in rodents linked to SNS activation. Reported effects of these compounds include activation of BAT thermogenesis and whole body energy expenditure in both rodents and humans (124), inhibition of adipogenesis (125) and stimulation of lipid catabolism (126) in white adipocyte cell models, and induction of browning of WAT in high-fat diet-fed rats supplemented with capsaicin (127). The bioactivity of capsaicin has been related to enhancement of catecholamine secretion from the adrenal medulla through 


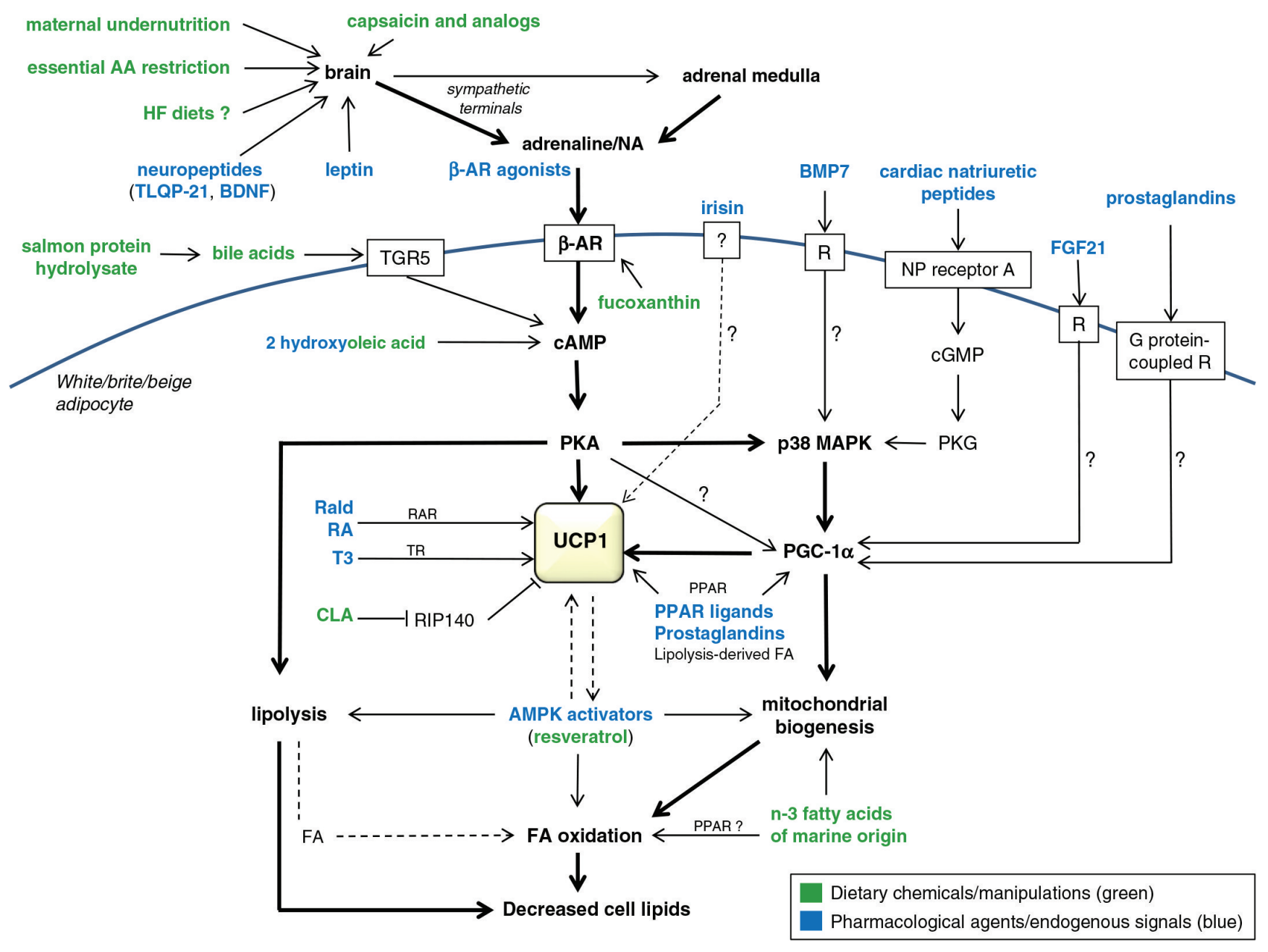

Figure 4. Pharmacological agents, endogenous signals and dietary chemicals/conditions that have been related to the browning of WAT.(121) (Adapted with permission from Elsevier)

activation of the SNS (128), and to binding to and activation of specific TRP channels within the gastrointestinal tract (47) and visceral adipose tissue (125).

Fucoxanthin is an allenic carotenoid present in the chloroplasts of edible brown algae. It is themost abundant of all carotenoids, accounting for more than $10 \%$ of the estimated total natural production of carotenoids.(129) Fucoxanthin metabolites accumulate in abdominal WAT. (130) Fucoxanthin or fucoxanthin-rich seaweed extract, alone or as part of mixtures with other selected agents, has been shown to counteract the development of dietary obesity and reduce abdominal WAT in obese animals through mechanisms that include the stimulation of WAT browning, with induction of UCP1 mRNA and protein expression and lipid catabolism-related genes in abdominal WAT.(131-135) Notably, fucoxanthin intake promotes WAT browning at doses at which it does not affect UCP1 expression in BAT, suggesting a WAT selective effect.(131)

Stimulatory effects of olive oil on the expression of UCPs have been described. Its previously demonstrated capacity to enhance the cyclic adenosine monophosphate (cAMP)/Protein Kinase A pathway (136) since phosphorylation of cAMP response element-binding protein (CREB) was drastically increased together with UCP1 expression in WAT of treated rats (137).

Conjugated linoleic acid is a group of dietary fatty acids that have received considerable attention due to their ability to significantly reduce adipose mass in a variety of species. The mechanisms by which CLA (specifically the trans-10, cis-12 isomer) depletes adipose mass may include a combination of increased apoptosis, decreased preadipocyte differentiation and lipogenesis, and increased fatty acid oxidation and energy expenditure in white adipocytes.(138) Intake of long-chain n-3 polyunsaturated fatty acids (PUFA) eicosapentaenoic acid (EPA) (20:5 n-3) and docosahexaenoic acid (DHA) (22:6 n-3), which are abundant in marine fish oil, reduces obesity and visceral fat mass in rodents and, although evidence is limited, possibly also in humans.(139) The anti-adiposity effect of n-3 PUFA does not result from a reduction in food intake, but rather 
reflects metabolic changes in several tissues (139), including increased UCP1-mediated adaptive thermogenesis in BAT (140) and oxidative metabolism in WAT (141).

Resveratrol (3,5,4'-trihydroxystilbene), a naturally occurring polyphenol present in grapes and other food vegetables, has many remarkable effects on energy metabolism and related aspects in mammals. These effects are believed to be due, at least in part, to resveratrol's ability to activate 5' AMP-activated protein kinase (AMPK) (possibly by interfering with mitochondrial respiration thus leading to an AMP/ATP imbalance) and, downstream of AMPK, sirtuin 1 (SIRT1) and peroxisome proliferatoractivated receptor gamma coactivator 1 - alpha (PGC-1 $\alpha$ ). (141) Resveratrol treatment has been shown to result in increased mitochondrial content and activity in skeletal muscle (142), liver (143) and BAT (142) in rodents. Resveratrol also impacts on white adipocyte biology, as it may inhibit adipogenesis of preadipose cells (144-146) and enhance fat mobilization in fully differentiated fat cells through stimulation of adipose triglyceride lipase (147) and negative modulation of PPAR $\gamma$ stability and transcriptional activity $(144,148,149)$. A browning effect is suggested by findings that resveratrol enhances mitochondrial DNA content and fatty acid oxidation together with UCP1 expression in mouse embryo fibroblast (MEF)-derived adipocytes (149) and UCP1 expression in maturing 3T3-L1 preadipocytes (150).

\section{Conclusion}

Knowledge regarding WAT browning and BAT activation could be useful in strategies to help prevent and manage obesity and related co-morbidities, such as type 2 diabetes and hepatosteatosis. Important advances have been made in the understanding of signaling pathways and compounds influencing browning of WAT and a large amount of data are currently available. Many treatments/manipulations that induce browning of WAT also induce the activity of classical

\section{References}

1. Wu J, Bostrom P, Sparks LM, Ye L, Choi JH, Giang AH, et al. Beige adipocytes are a distinct type of thermogenic fat cell in mouse and human. Cell. 2012; 150: 366-76.

2. Nedergaard J, Bengtsson T, Cannon B. Unexpected evidence for active brown adipose tissue in adult humans. Am J Physiol Endocrinol Metab. 2007; 293: E444-52.

3. van Marken Lichtenbelt WD, Vanhommerig JW, Smulders NM, Drossaerts JM, Kemerink GJ, Bouvy ND, et al. Cold-activated brown adipose tissue in healthy men. N Engl J Med. 2009; 360: 1500-8.

4. Cypess AM, Lehman S, Williams G, Tal I, Rodman D, Goldfine AB, et al. Identification and importance of brown adipose tissue in adult humans. N Engl J Med. 2009; 360: 1509-17.

5. Virtanen KA, Lidell ME, Orava J, Heglind M, Westergren R, Niemi $\mathrm{T}$, et al. Functional brown adipose tissue in healthy adults. $\mathrm{N}$ Engl $\mathrm{J}$ Med. 2009; 360: 1518-25.

6. Zingaretti MC, Crosta F, Vitali A, Guerrieri M, Frontini A, Cannon B, et al. The presence of UCP1 demonstrates that metabolically active adipose tissue in the neck of adult humans truly represents brown adipose tissue. FASEB J. 2009; 23: 3113-20.

7. Saito M, Okamatsu-Ogura Y, Matsushita M, Watanabe K, Yoneshiro $\mathrm{T}$, Nio-Kobayashi $\mathrm{J}$, et al. High incidence of metabolically active brown adipose tissue in healthy adult humans: effects of cold exposure and adiposity. Diabetes. 2009; 58: 1526-31.

8. Ishibashi J, Seale P. Medicine. Beige can be slimming. Science. 2010; 328: 1113-4.

9. Petrovic N, Walden TB, Shabalina IG, Timmons JA, Cannon B, Nedergaard J. Chronic peroxisome proliferator-activated receptor gamma (PPARgamma) activation of epididymally derived white adipocyte cultures reveals a population of thermogenically competent, UCP1-containing adipocytes molecularly distinct from classic brown adipocytes. J Biol Chem. 2010; 285: 7153-64.

10. Seale P, Bjork B, Yang W, Kajimura S, Chin S, Kuang S, et al. PRDM16 controls a brown fat/skeletal muscle switch. Nature. 2008; 454: 961-7.

11. Coulter AA, Bearden CM, Liu X, Koza RA, Kozak LP. Dietary fat interacts with QTLs controlling induction of Pgc-1 alpha and Ucp1 during conversion of white to brown fat. Physiol. Genomics. 2003; 14: 139-47.

12. Guerra C, Koza RA, Yamashita H, Walsh K, Kozak LP. Emergence of brown adipocytes in white fat in mice is under genetic control. Effects on body weight and adiposity. J Clin Invest. 1998; 102: 41220.

13. Koza RA, Hohmann SM, Guerra C, Rossmeisl M, Kozak LP. Synergistic gene interactions control the induction of the mitochondrial uncoupling protein (Ucp1) gene in white fat tissue. J Biol Chem. 2000; 275: 34486-92.

14. Xue B, Coulter A, Rim JS, Koza RA, Kozak LP. Transcriptional synergy and the regulation of Ucp1 during brown adipocyte induction in white fat depots. Mol Cell Biol. 2005; 25: 8311-22.

15. Xue B, Rim JS, Hogan JC, Coulter AA, Koza RA, Kozak LP. Genetic variability affects the development of brown adipocytes in white fat but not in interscapular brown fat. J Lipid Res. 2007; 48: 41-51.

16. Himms-Hagen J, Cui J, Danforth E Jr, Taatjes DJ, Lang SS, Waters BL, et al. Effect of CL-316,243, a thermogenic beta 3-agonist, on energy balance and brown and white adipose tissues in rats. Am J Physiol. 1994; 266: R1371-82.

17. Sharp LZ, Shinoda K, Ohno H, Scheel DW, Tomoda E, Ruiz L, et al. Human BAT possesses molecular signatures that resemble beige/ brite cells. PLoS ONE. 2012; 7: e49452. doi: 10.1371/journal. pone. 0049452 .

18. Jespersen NZ, Larsen TJ, Peijs L, Daugaard S, Homoe P, Loft A, et al. A classical brown adipose tissue: mRNA signature party overlaps with brite in the supraclavicular region of adult humans. Cell Metab. 2012; 17: 798-805.

19. Muller MJ, Bossy-Westphal A. Adaptive thermogenesis with weight loss in humans. Obesity. 2013; 21: 218-28.

20. Tremblay A, Major GC, Doucet E, Trayhurn P, Astrup A. Role of adaptive thermogenesis in unsuccessful weight-loss intervention. Future Lipidol. 2007; 2: 651-8.

21. Tremblay A, Royer MM, Chaput JP, Doucet E. Adaptive thermogenesis 
can make a difference in the ability of obese individuals to lose body weight. Int J Obes. 2013; 37: 759-64.

22. Rothwell NJ, Stock MJ. A role for brown adipose tissue in dietinduced thermogenesis. Nature. 1979; 281: 31-5.

23. Leibel RL, Rosenbaum M, Hirsch J. Changes in energy expenditure resulting from altered body weight. N Engl J Med. 1995; 332: 62168.

24. Rosenbaum M, Hirsch J, Murphy E, Leibel RL. Effects of changes in body weight on carbohydrate metabolism, catecholamine excretion, and thyroid function. Am J Clin Nutr. 2000; 71: 1421-32.

25. McGuire MT, Wing RR, Klem ML, Seagle HM, Hill JO. Long-term maintenance of weight loss: do people who lose weight through various weight loss methods use different behaviors to maintain their weight? Int J Obes. 1998; 22: 572-7.

26. Rosenbaum M, Leibel RL. Adaptive thermogenesis in humans. Int $\mathrm{J}$ Obes (Lond). 2010; 34: S47-55.

27. Major GC, Doucet E, Trayhurn P, Astrup A, Tremblay A. Clinical significance of adaptive thermogenesis. Int J Obes (Lond). 2007; 31: 204-12.

28. Doucet E, St-Pierre S, Alméras N, Després JP, Bouchard C, Tremblay A. Evidence for the existence of adaptive thermogenesis during weight loss. Br J Nutr. 2001; 85: 715-23.

29. Collins S, Cao W, Robidoux J. Learning new tricks from old dogs: beta-adrenergic receptors teach new lessons on firing up adipose tissue metabolism. Mol Endocrinol. 2004; 18: 2123-31.

30. Whittle AJ, López M, Vidal-Puig A. Using brown adipose tissue to treat obesity - the central issue. Trends Mol Med. 2011; 17: 405-11.

31. Wu J, Cohen P, Spiegelman BM. Adaptive thermogenesis in adipocytes: is beige the new brown? Genes Develop. 2013; 27: 23450 .

32. Cannon B, Nedergaard J. Brown adipose tissue: function and physiological significance. Physiol Rev. 2004; 84: 277-359.

33. Fedorenko A, Lishko PV, Kirichok Y. Mechanism of fatty-aciddependent UCP1 uncoupling in brown fat mitochondria. Cell. 2012; 151: 400-13.

34. Enerbäck S. Human brown adipose tissue. Cell Metab. 2010; 11: 24852.

35. Virtanen KA, Lidell ME, Orava J, Heglind M, Westergren R, Niemi $\mathrm{T}$, et al. Functional brown adipose tissue in healthy adults. $\mathrm{N}$ Engl $\mathrm{J}$ Med. 2009; 360: 1518-25.

36. Williams KJ. Molecular processes that handle-and mishandle-dietary lipids. J Clin Invest. 2008; 118: 3247-59.

37. Bartelt A, Bruns OT, Reimer R, Hohenberg H, Ittrich H, Peldschus K, et al. Brown adipose tissue activity controls triglyceride clearance. Nat Med. 2011; 17: 200-5.

38. Rothwell NJ, Stock MJ. Effects of age on diet induced thermogenesis and brown adipose tissue metabolism in the rat. Int J Obes. 1983; 7: 583-9.

39. Gesta S, Tseng YH, Kahn CR. Developmental origin of fat: tracking obesity to its source. Cell. 2007; 131: 242-56.

40. Stanford KI, Middlebeek RJW, Townsend KL, An D, Nygaard $\mathrm{EB}$, Hitchcox KM, et al. Brown adipose tissue regulates glucose homeostasis and insulin sensitivity. J Clin Invest 2013; 123: 215-23.

41. Nakamura K. Central circuitries for body temperature regulation and fever. Am J Physiol Regul Integr Comp Physiol. 2011; 301: R120728.

42. Yoneshiro T, Aita S, Matsushita M, Kameya T, Nakada K, Kawai Y, et al. Brown adipose tissue, whole-body energy expenditure, and thermogenesis in healthy adult men. Obesity (Silver Spring). 2011; 19: 13-6.

43. Orava J, Nuutila P, Lidell ME, Oikonen V, Noponen T, Viljanen T, et al. Different metabolic responses of human brown adipose tissue to activation by cold and insulin. Cell Metab. 2011; 14: 272-9.
44. Ouellet V, Labbé SM, Blondin DP, Phoenix S, Guérin B, Haman F, et al. Brown adipose tissue oxidative metabolism contributes to energy expenditure during acute cold exposure in humans. J Clin Invest. 2012; 122: 545-52.

45. Tajino K, Hosokawa H, Maegawa S, Matsumura K, Dhaka A, Kobayashi S. Cooling-sensitive TRPM8 is thermostat of skin temperature against cooling. PLoS One. 2011; 6: e17504. doi: 10.1371/journal.pone.0017504.

46. Shintaku K, Uchida K, Suzuki Y, Zhou Y, Fushiki T, Watanabe T, et al. Activation of transient receptor potential A1 by a non-pungent capsaicin like compound, capsiate. Br J Pharmacol. 2011; 165: 1476-86.

47. Ono K, Tsukamoto-Yasui M, Hara-Kimura Y, Inoue N, Nogusa Y, Okabe Y, et al. Intragastric administration of capsiate, a transient receptor potential channel agonist, triggers thermogenic sympathetic responses. J Appl Physiol. 2011; 110: 789-98.

48. Yoneshiro T, Aita S, Matsushita M, Kayahara T, Kameya T, Kawai $\mathrm{Y}$, et al. Recruited brown adipose tissue as an antiobesity agent in humans. J Clin Invest. 2013; 123: 3404-8.

49. Atit R, Sgaier SK, Mohamed OA, Taketo MM, Dufort D, Joyner AL, et al. Beta-catenin activation is necessary and sufficient to specify the dorsal dermal fate in the mouse. Dev Biol. 2006; 296: 164-76.

50. Timmons JA, Wennmalm K, Larsson O, Walden TB, Lassmann T, Petrovic N, et al. Myogenic gene expression signature establishes that brown and white adipocytes originate from distinct cell lineages. Proc Natl Acad Sci USA. 2007; 104: 4401-6.

51. Walden TB, Hansen IR, Timmons JA, Cannon B, Nedergaard J. Recruited vs nonrecruited molecular signatures of brown, "brite", and white adipose tissues. Am J Physiol Endocrinol Metab. 2012; 302: E19-31.

52. Lepper C, Fan CM. Inducible lineage tracing of Pax7-descendant cells reveals embryonic origin of adult satellite cells. Genesis. 2010; 48: 424-36.

53. Cinti S. Reversible physiological transdifferentiation in the adipose organ. Proc Nutr Soc. 2009; 68: 340-9.

54. Cousin B, Cinti S, Morroni M, Raimbault S, Ricquier D, Penicaud L, et al. Occurrence of brown adipocytes in rat white adipose tissue: Molecular and morphological characterization. J Cell Sci. 1992; 103: 931-42.

55. Ghorbani M, Himms-Hagen J. Appearance of brown adipocytes in white adipose tissue during CL 316,243-induced reversal of obesity and diabetes in Zucker fa/fa rats. Int J Obes Relat Metab Disord. 1997; 21: 465-75.

56. Barbatelli G, Murano I, Madsen L, Hao Q, Jimenez M, Kristiansen K, et al. The emergence of cold-induced brown adipocytes in mouse white fat depots is determined predominantly by white to brown adipocyte transdifferentiation. Am J Physiol Endocrinol Metab. 2010; 298: E1244-53.

57. Seale P, Conroe HM, Estall J, Kajimura S, Frontini A, Ishibashi J, et al. Prdm16 determines the thermogenic program of subcutaneous white adipose tissue in mice. J Clin Invest. 2011; 121: 96-105.

58. Owens B. The changing colour of fat. Nature. 2013; 508: S52-3.

59. Xue Y, Petrovic N, Cao R, Larsson O, Lim S, Chen S, et al. Hypoxia-independent angiogenesis in adipose tissues during cold acclimation. Cell Metab. 2009; 9: 99-109.

60. Shimizu I, Aprahamian T, Kikuchi R, Shimizu A, Papanicolau KN, MacLauchlan S, et al. Vascular rarefaction mediates whitening of brown fat in obesity. J Clin Invest. 2014; 124: 2099-112.

61. Boström P, Wu J, Jedrychowski MP, Korde A, Ye L, Lo JC, et al. A PGC1-a-dependent myokine that drives brown-fat-like development of white fat and thermogenesis. Nature. 2012; 481: 463-8.

62. Fisher FM, Kleiner S, Douris N, Fox EC, Mepani RJ, Verdeguer F, et al. FGF21 regulates PGC-1a and browning of white adipose tissues 
in adaptive thermogenesis. Genes Dev. 2012; 26: 271-81.

63. Cederberg A, Grønning LM, Ahrén B, Taskén K, Carlsson P, Enerbäck S. FOXC2 is a winged helix gene that counteracts obesity, hypertriglyceridemia, and diet-induced insulin resistance. Cell. 2001; 106: 563-73.

64. Powelka AM, Seth A, Virbasius JV, Kiskinis E, Nicoloro SM, Guilherme A, et al. Suppression of oxidative metabolism and mitochondrial biogenesis by the transcriptional corepressor RIP140 in mouse adipocytes. J Clin Invest. 2006; 116; 125-36.

65. Tsukiyama-Kohara K, Poulin F, Kohara M, DeMaria CT, Cheng $\mathrm{A}, \mathrm{Wu} \mathrm{Z}$, et al. Adipose tissue reduction in mice lacking the translational inhibitor 4E-BP1. Nat Med. 2001; 7: 1128-32.

66. Picard F, Géhin M, Annicotte J, Rocchi S, Champy MF, O'Malley BW, et al. SRC-1 and TIF2 control energy balance between white and brown adipose tissues. Cell. 2002; 111: 931-41.

67. Scimè A, Grenier G, Huh MS, Gillespie MA, Bevilacqua L, Harper $\mathrm{ME}$, et al. $\mathrm{Rb}$ and $\mathrm{p} 107$ regulate preadipocyte differentiation into white versus brown fat through repression of PGC-1alpha. Cell Metab. 2005; 2: 283-95.

68. Qiang L, Wang L, Kon N, Zhao W, Lee S, Zhang Y, et al. Brown remodeling of white adipose tissue by SirT1-dependent deacetylation of PPAR $\gamma$. Cell. 2012; 150: 620-32.

69. Wasserman F. The fat organs of man: development, structure and systematic place of the so called adipose tissue. A Zellforsch Microskop Anat Abt Histochem. 1926; 3: 325-9.

70. Rosen ED, Spiegelman BM. Adipocytes as regulators of energy balance and glucose homeostasis. Nature. 2006; 444: 847-53.

71. Friedman JM. Leptin at $14 \mathrm{y}$ of age: an ongoing story. Am J Clin Nutr. 2009; 89: 973S-9S.

72. Himms-Hagen J. Brown adipose tissue and cold-acclimation. In: Trayhurn P, Nicholls AD, editors. Brown Adipose Tissue. London: Edward Arnold; 1986. p.214.

73. Ricquier D. Fundamental mechanisms of thermogenesis. C R Biol. 2006; 329: 578-86; discussion 653-5.

74. Smorlesi A, Frontini A, Giordano A, Cinti S. The adipose organ: white-brown adipocyte plasticity and metabolic inflammation. Obes Res. 2012; 13 (suppl. 2): 83-96.

75. Cinti S. The Adipose Organ. Milan: Kurtis; 1999.

76. Cinti S. The adipose organ. Prostaglandins Leukot Essent Fatty Acids. 2005; 73: 9-15.

77. Himms-Hagen J, Melnyk A, Zingaretti MC, Ceresi E, Barbatelli G, Cinti S. Multilocular fat cells in WAT of CL-316243-treated rats derive directly from white adipocytes. Am J Physiol Cell Physiol. 2000; 279: C670-81 .

78. Granneman JG, Li P, Zhu Z, Lu Y. Metabolic and cellular plasticity in white adipose tissue I: effects of beta3-adrenergic receptor activation. Am J Physiol Endocrinol Metab. 2005; 289: E608-16.

79. Lowell BB, S-Susulic V, Hamann A, Lawitts JA, Himms-Hagen J, Boyer BB. et al. Development of obesity in transgenic mice after genetic ablation of brown adipose tissue. Nature. 1993; 366: 740-2.

80. Bachman ES, Dhillon H, Zhang CY, Cinti S, Bianco AC, Kobilka BK, et al. betaAR signaling required for diet induced thermogenesis and obesity resistance. Science. 2002; 297: 843-5.

81. Kopecky J, Clarke G, Enerbäck S, Spiegelman B, Kozak LP. Expression of the mitochondrial uncoupling protein gene from the aP2 gene promoter prevents genetic obesity. J Clin Invest. 1995; 96 : 2914-23.

82. Vitali A, Murano I, Zingretti MC, Frontini A, Ricquier D, Cinti S. The adipose organ of obesity-prone $\mathrm{C} 57 \mathrm{BL} / 6 \mathrm{~J}$ mice is composed of mixed white and brown adipocytes. J Lipid Res. 2012; 53: 619-29.

83. Young P, Arch JR, Ashwell M. Brown adipose tissue in the parametrial fat pad of the mouse. FEBS Lett. 1984; 167: 10-14.

84. Schulz TJ, Huang TL, Tran TT, Zhang H, Townsend KL, Shadrach
$\mathrm{JL}$, et al. Identication of inducible brown adipocyte progenitors residing in skeletal muscle and white fat. Proc Natl Acad Sci USA. 2011; 108: 143-8

85. Lazar MA. Developmental biology. How now, brown fat? Science. 2008; 321: 1048-9.

86. Xue B, Rim JS, Hogan JC, Coulter AA, Koza RA, Kozak LP. Genetic variability affects the development of brown adipocytes in white fat but not in interscapular brown fat. J Lipid Res. 2007; 48: 41-51.

87. Loncar D. Convertible adipose tissue in mice. Cell Tissue Res. 1991; 266: 149-61.

88. Tchkonia T, Lenburg M, Thomou T, Giorgadze N, Frampton G, Pirtskhalava $\mathrm{T}$, et al. Identification of depot-specific human fat cell progenitors through distinct expression profiles and developmental gene patterns. Am J Physiol Endocrinol Metab. 2007; 292: E298307.

89. Murano I, Barbatelli G, Giordano A, Cinti S. Noradrenergic parenchymal nerve fiber branching after cold acclimatisation correlates with brown adipocyte density in mouse adipose organ. J Anat. 2009; 214: 171-8.

90. De Matteis R, Arch JR, Petroni ML, Ferrari D, Cinti S, Stock MJ. Immunohistochemical identification of the beta(3)-adrenoceptor in intact human adipocytes and ventricular myocardium: effect of obesity and treatment with ephedrine and caffeine. Int J Obes Relat Metab Disord. 2002; 26: 1442-50.

91. Collins S, Surwit RS. The beta-adrenergic receptors and the control of adipose tissue metabolism and thermogenesis. Recent Prog Horm Res. 2001; 56: 309-28.

92. Cinti S. Transdifferentiation properties of adipocytes in the adipose organ. Am J Physiol Endocrinol Metab. 2009; 297: E977.

93. Kopecky J, Hodny Z, Rossmeisl M, Syrovy I, Kozak LP. Reduction of dietary obesity in aP2-Ucp transgenic mice: physiology and adipose tissue distribution. Am J Physiol 1996; 270: E768-75.

94. Ghorbani M, Claus TH, Himms-Hagen J. Hypertrophy of brown adipocytes in brown and white adipose tissues and reversal of dietinduced obesity in rats treated with a beta3-adrenoceptor agonist. Biochem Pharmacol. 1997; 54: 121-31.

95. Almind K, Manieri M, Sivitz WI, Cinti S, Kahn CR. Ectopic brown adipose tissue in muscle provides a mechanism for differences in risk of metabolic syndrome in mice. Proc Natl Acad Sci USA. 2007; 104: 2366-71

96. Madsen L, Petersen RK, Sørensen MB, Jørgensen C, Hallenborg P, Pridal L, et al. Adipocyte differentiation of 3T3-L1 preadipocytes is dependent on lipoxygenase activity during the initial stages of the differentiation process. Biochem J. 2003; 375: 539-49.

97. Harms M, Seale P. Brown and beige fat: development, function and therapeutic potential. Nat Med. 2013; 19: 1252-63.

98. Sanchez-Gurmaches J, Hung CM, Sparks CA, Tang Y, Li H, Guertin DA. PTEN loss in the Myf5 lineage redistributes body fat and reveals subsets of white adipocytes that arise from Myf5 precursors. Cell Metab. 2012; 16: 348-62.

99. Forner F, Kumar C, Luber CA, Fromme T, Klingenspor M, Mann M. Proteome differences between brown and white fat mitochondria reveal specialized metabolic functions. Cell Metab. 2009; 10: $324-$ 35.

100. Wang QA, Tao C, Gupta RK, Scherer PE. Tracking adipogenesis during white adipose tissue development, expansion and regeneration. Nat Med. 2013; 19: 1338-44.

101. Rosenwald M, Perdikari A, Rülicke T, Wolfrum C. Bi-directional interconversion of brite and white adipocytes. Nat Cell Biol. 2013; 15: 659-67.

102. Seale P, Kajimura S, Yang W, Chin S, Rohas LM, Uldry M, et al. Transcriptional control of brown fat determination by PRDM16. Cell Metab. 2007; 6: 38-54 
103. Lee P, Zhao JT, Swarbrick MM, Gracie G, Bova R, Greenfield JR, et $a l$. High prevalence of brown adipose tissue in adult humans. J Clin Endocrinol Metab. 2011; 96: 2450-5.

104. Tseng YH, Kokkotou E, Schulz TJ, Huang TL, Winnay JN, Taniguchi $\mathrm{CM}$, et al. New role of bone morphogenetic protein 7 in brown adipogenesis and energy expenditure. Nature 2008; 454: 1000-4.

105. Schulz TJ, Huang P, Huang TL, Xue R, McDougall LE, Townsend $\mathrm{KL}$, et al. Brown-fat paucity due to impaired BMP signalling induces compensatory browning of white fat. Nature 2013; 495: 379-83.

106. Ohno H, Shinoda K, Spiegelman BM, Kajimura S. PPAR $\gamma$ agonists induce a white-to-brown fat conversion through stabilization of PRDM16 protein. Cell Metab. 2012; 15: 395-404.

107. Olshansky SJ, Passaro DJ, Hershow RC, Layden J, Carnes BA, Brody $\mathrm{J}$, et al. A potential decline in life expectancy in the United States in the 21st century. N Engl J Med. 2005; 352: 1138-45.

108. Bordicchia M, Liu D, Amri EZ, Ailhaud G, Dessì-Fulgheri P, Zhang $\mathrm{C}$, et al. Cardiac natriuretic peptides act via $38 \mathrm{MAPK}$ to induce the brown fat thermogenic program in mouse and human adipocytes. $\mathrm{J}$ Clin Invest. 2012; 122: 1022-36.

109. Chang L, Villacorta L, Li R, Hamblin M, Xu W, Dou C, et al. Loss of perivascular adipose tissue on peroxisome proliferator-activated receptor- $\gamma$ deletion in smooth muscle cells impairs intravascular thermoregulation and enhances atherosclerosis. Circulation. 2012; 126: 1067-78.

110. Xu X, Ying Z, Cai M, Xu Z, Li Y, Jiang SY, et al. Exercise ameliorates high-fat diet-induced metabolic and vascular dysfunction, and increases adipocyte progenitor cell population in brown adipose tissue. Am J Physiol Regul Integr Comp Physiol. 2011; 300: R111525.

111. Wu J, Spiegelman BM. Irisin ERKs the fat. Diabetes 2014; 63: 381-3.

112. Whittle AJ, Carobbio S, Martins L, Slawik M, Hondares E, Vázquez MJ, et al. BMP8B increases brown adipose tissue thermogenesis through both central and peripheral actions. Cell. 2012; 149: 87185.

113. Sellayah D, Bharaj P, Sikder D. Orexin is required for brown adipose tissue development, differentiation, and function. Cell Metab. 2011; 14: 478-90.

114. Pekkala S, Wiklund PK, Hulmi JJ, Ahtiainen JP, Horttanainen M, Pöllänen E, et al. Are skeletal muscle FNDC5 gene expression and irisin release regulated by exercise and related to health? J Physiol. 2013; 591: 5393-400.

115. Lecker SH, Zavin A, Cao P, Arena R, Allsup K, Daniels KM, et al. Expression of the irisin precursor FNDC5 in skeletal muscle correlates with aerobic exercise performance in patients with heart failure. Circ Heart Fail. 2012; 5: 812-8.

116. Park KH, Zaichenko L, Brinkoetter M, Thakkar B, Sahin-Efe A, Joung KE, et al. Circulating irisin in relation to insulin resistance and the metabolic syndrome. J Clin Endocrinol Metab. 2013; 98: 4899-907.

117. Choi YK, Kim MK, Bae KH, Seo HA, Jeong JY, Lee WK, et al. Serum irisin levels in new-onset type 2 diabetes. Diabetes Res Clin Pract. 2013; 100: 96-101.

118. Gaich G, Chien JY, Fu H, Glass LC, Deeg LC, Holland WL, et al. The effect of LY2405319, an FGF21 analog, in obese human subjects with type 2 diabetes. Cell Metab. 2013; 18: 333-40.

119. Chainani-Wu N, Weidner G, Purnell DM, Frenda S, Merritt-Worden T, Kemp C, et al. Relation of B-type natriuretic peptide levels to body mass index after comprehensive lifestyle changes. Am J Cardiol. 2010; 105: 1570-6.

120. Sengenès C, Berlan M, De Glisezinski I, Lafontan M, Galitzky J. Natriuretic peptides: a new lipolytic pathway in human adipocytes. FASEB J. 2000; 14: 1345-51.
121. Bonet ML, Oliver P, Palou A. Pharmacological and nutritional agents promoting browning of white adipose tissue. Biochim Biophys Act. 2013; 1831: 969-85.

122. Vegiopoulos A, Müller-Decker K, Strzoda D, Schmitt I, Chichelnitskiy E, Ostertag A, et al. Cyclooxygenase-2 controls energy homeostasis in mice by de novo recruitment of brown adipocytes. Science. 2010; 328: 1158-61.

123. Madsen L, Pedersen LM, Lillefosse HH, Fjaere E, Bronstad I, Hao $\mathrm{Q}$, et al. UCP1 induction during recruitment of brown adipocytes in white adipose tissue is dependent on cyclooxygenase activity. PLoS One. 2010; 5: e11391. doi: 10.1371/journal.pone.0011391.

124. Yoneshiro T, Aita S, Kawai Y, Iwanaga T, Saito M. Nonpungent capsaicin analogs (capsinoids) increase energy expenditure through the activation of brown adipose tissue in humans. Am J Clin Nutr. 2012; 95: 845-50.

125. Zhang LL, Yan Liu D, Ma LQ, Luo ZD, Cao TB, Zhong J, et al. Activation of transient receptor potential vanilloid type-1 channel prevents adipogenesis and obesity. Circ Res. 2007; 100: 1063-70.

126. Lee MS, Kim CT, Kim IH, Kim Y. Effects of capsaicin on lipid catabolism in 3T3-L1 adipocytes. Phytother Res. 2011; 25: 935-9.

127. Joo JI, Kim DH, Choi JW, Yun JW. Proteomic analysis for antiobesity potential of capsaicin on white adipose tissue in rats fed with a high fat diet. J Proteome Res. 2010; 9: 2977-87.

128. Watanabe T, Kawada T, Yamamoto M, Iwai K. Capsaicin, a pungent principle of hot red pepper, evokes catecholamine secretion from the adrenal medulla of anesthetized rats. Biochem Biophys Res Commun. 1987; 142: 259-64.

129. Miyashita K, Nishikawa S, Beppu F, Tsukui T, Abe M, Hosokawa $\mathrm{M}$. The allenic carotenoid fucoxanthin, a novel marine nutraceutical from brown seaweeds. J Sci Food Agric. 2011; 91: 1166-74.

130. Sangeetha RK, Bhaskar N, Divakar S, Baskaran V. Bioavailability and metabolism of fucoxanthin in rats: structural characterization of metabolites by LC-MS (APCI). Mol Cell Biochem. 2010; 333: 299-310.

131. Maeda H, Hosokawa M, Sashima T, Funayama K, Miyashita K. Fucoxanthin from edible seaweed, Undaria pinnatifida, shows antiobesity effect through UCP1 expression in white adipose tissues. Biochem Biophys Res Commun. 2005; 332: 392-7.

132. Maeda H, Hosokawa M, Sashima T, Funayama K, Miyashita K. Effect of medium-chain triacylglycerols on anti-obesity effect of fucoxanthin. J Oleo Sci. 2007; 56: 615-21.

133. Jeon SM, Kim HJ, Woo MN, Lee MK, Shin YC, Park YB, et al. Fucoxanthin-rich seaweed extract suppresses body weight gain and improves lipid metabolism in high-fat-fed C57BL/6J mice. Biotechnol J. 2010; 5: 961-9.

134. Okada T, Mizuno Y, Sibayama S, Hosokawa M, Miyashita K. Antiobesity effects of Undaria lipid capsules prepared with scallop phospholipids. J Food Sci. 2011; 76: H2-6.

135. Hu X, Li Y, Li C, Fu Y, Cai F, Chen Q, et al. Combination of fucoxanthin and conjugated linoleic acid attenuates body weight gain and improves lipid metabolism in high-fat diet-induced obese rats. Arch Biochem Biophys. 2012; 519: 59-65.

136. Alemany R, Vögler O, Terés S, Egea C, Baamonde C, Barceló F, et al. Antihypertensive action of 2-hydroxyoleic acid in SHRs via modulation of the protein kinase A pathway and Rho kinase. J Lipid Res. 2006; 47: 1762-70.

137. Vögler O, López-Bellan A, Alemany R, Tofé S, González M, Quevedo $\mathrm{J}$, et al. Structure-effect relation of $\mathrm{C} 18$ long-chain fatty acids in the reduction of body weight in rats. Int J Obes (Lond.). 2008; 32: 46473.

138. House RL, Cassady JP, Eisen EJ, McIntosh MK, Odle J. Conjugated linoleic acid evokes de-lipidation through the regulation of genes controlling lipid metabolism in adipose and liver tissue. Obes Rev. 2005; 6: 247-58. 
139. Buckley JD, Howe PR. Long-chain omega-3 polyunsaturated fatty acids may be beneficial for reducing obesity-a review. Nutrients 2010; 2: 1212-30.

140. Flachs P, Horakova O, Brauner P, Rossmeisl M, Pecina P, Franssenvan Hal N, et al. Polyunsaturated fatty acids of marine origin upregulate mitochondrial biogenesis and induce beta-oxidation in white fat. Diabetologia. 2005; 48: 2365-75.

141. Timmer S, Auwerx J, Schrauwen P. The journey of resveratrol from yeast to human. Aging (Albany NY). 2012; 4: 146-58.

142. Lagouge M, Argmann C, Gerhart-Hines Z, Meziane H, Lerin C, Daussin F, et al. Resveratrol improves mitochondrial function and protects against metabolic disease by activating SIRT1 and PGC1alpha. Cell. 2006; 127: 1109-22.

143. Baur JA, Pearson KJ, Price NL, Jamieson HA, Lerin C, Kalra A, et al. Resveratrol improves health and survival of mice on a high-calorie diet. Nature. 2006; 444: 337-42.

144. Picard F, Kurtev M, Chung N, Topark-Ngarm A, Senawong T, Machado De Oliveira R, et al. Sirt1 promotes fat mobilization in white adipocytes by repressing PPAR-gamma. Nature. 2004; 429: 771-6.

145. Bai L, Pang WJ, Yang YJ, Yang GS. Modulation of Sirt1 by resveratrol and nicotinamide alters proliferation and differentiation of pig preadipocytes. Mol Cell Biochem. 2008; 307: 129-40.

146. Rayalam S, Yang JY, Ambati S, Della-Fera MA, Baile CA. Resveratrol induces apoptosis and inhibits adipogenesis in 3T3-L1 adipocytes, Phytother Res. 2008; 22: 1367-71.

147. Lasa A, Schweiger M, Kotzbeck P, Churruca I, Simón E, Zechner R, et al. Resveratrol regulates lipolysis via adipose triglyceride lipase. J Nutr Biochem. 2012; 23: 379-84.

148. Szkudelska K, Nogowski L, Szkudelski T. Resveratrol, a naturally occurring diphenolic compound, affects lipogenesis, lipolysis and the antilipolytic action of insulin in isolated rat adipocytes. J Steroid Biochem Mol Biol. 2009; 113: 17-24.

149. Floyd ZE, Wang ZQ, Kilroy G, Cefalu WT. Modulation of peroxisome proliferator-activated receptor gamma stability and transcriptional activity in adipocytes by resveratrol. Metabolism. 2008; 57: S32-8.

150. Mercader J, Palou A, Bonet ML. Resveratrol enhances fatty acid oxidation capacity and reduces resistin and Retinol-Binding Protein 4 expression in white adipocytes. J Nutr Biochem. 2011; 22: 82834. 